\title{
Women's Power and Electability in Southeast Sulawesi: A Case Study for Provincial and National Legislative Candidate
}

\author{
La Husen Zuada Universitas Tadulako, Indonesia \\ Rekho Adriadi Universitas Muhammadiyah Bengkulu, Indonesia \\ Abdul Kadir Universitas Halu Oleo, Indonesia
}

\begin{abstract}
This research examined the role of power in increasing the choice of women legislative candidates. Women's electability has increased in the four election periods $(2004,2009,2014$, 2019) in Southeast Sulawesi. The interesting thing on the results of the 2014 election found that eight of the nine elected women legislators are the wives of four active regents, three former regents, and the governor during the election process. They are the 'new face' in the politics and previously have never become a legislative member, except become the Chair of the Dharma Wanita who are accompanying their husbands as regional heads. The reasons for women's electability in the legislative underlie this research. Through a qualitative approach, this study found that the power resources were owned by their families (money and bureaucracy) and personal abilities were also the factors of choice. In the context of Southeast Sulawesi, this study found a change in the vote mobilization strategies. Ethnic mobilization (locality) that characterized the local politics of Southeast Sulawesi had a smaller impact on the election, whereas money politics (economic resource) and bureaucratic politicization (normative) had a strong impact on the voters. This study enriches the findings in the vote mobilization strategies, namely the combination of locality/friends-neighbors (ethnicity), money and bureaucracy as the factors of politicians' electability.
\end{abstract}

Keywords

Power; Election; Legislative Candidates; Women

\section{INTRODUCTION}

Regulations require $30 \%$ women's representation in the imaging process and various institutional engineering of the

La Husen Zuada is a lecturer at the Department of Government Science, Universitas Tadulako, Indonesia. His research foci on local politics, elections, political parties and political economy. Email: husenzuadaui @gmail.com.

Rekho Adriadi is a lecturer at the Department of Public Administration, Universitas Muhammadiyah Bengkulu, Indonesia. His research foci on local politics, public policy and government studies.

Abdul Kadir is a lecturer at the Department of Public Administration, Universitas Halu Oleo, Indonesia. His research foci on public administration and public policy.

I am thankful to our institution for providing awards and financial support in the process of publishing our writing. electoral system --zipper system, majority vote, open system, and various other rules-- are not automatically able to boost the number of women's representation to pass in the legislative (Afrianty, 2015). Some researches written by Berg (2015) showed that the lack of electability of female candidates was influenced by several factors, namely culture, socialeconomy, politics, family networks and participation in social movements, as well as status and position (Darwin, 2017; 
Marwah, 2019). Departing from that, it is not an easy thing to increase women's representation in the legislative.

A rare view occurred in Southeast Sulawesi, where since the enactment of women's quota in the 2004 election, the number of women's representation at the Provincial (Regional People's Representative Councils) and National (House of People's Representatives) levels in the Southeast Sulawesi electoral district has increased, although the number has never reached $30 \%$. Furthermore, it is such enough interesting thing that the elected women legislators are the wives of active regional heads and former regional heads during the election process (ShairRosenfield, 2012).

The victory of women legislators in Southeast Sulawesi is fairly easy, considering that they have no personal appeal, are not party cadres who have the experience requirements and activist background, and who go through a long struggle process. On the contrary, their electability cannot be separated from the power network held by their husbands when serving as regional head. The bureaucratic politicization, money politics and 'repayment' politics are the instruments which support the electability of these 'housewives'. The husband's power network has become an advantage for them so that they are able to get rid of male politicians, as well as other women politicians who have experience requirements. Therefore, it appears that the power network has a role in increasing the number of women's representation in the legislative.

In the 2019 election, the incumbent women legislative members re-nominated as legislative members at the provincial (Regional People's Representative Councils) and national (House of People's Representatives) levels. This momentum proved that the 'housewives' who have the power network, whether they succeed in winning the election even though they were no longer supported by their husband's power, or instead they failed. Based on this brief description, this paper aims to discuss this issue by asking the main question: what is the power source used by women candidates in gaining electoral support?

In order to answer that question, secondary data were collected, namely the results of the 2014 and 2019 elections and various media reports. In addition, primary data was also collected through interviews with the informants. The collected data focused on women candidates who were elected in the 2014 and 2019 elections at the Provincial House of Representatives (DPRD Province) and House of People's Representatives (DPR-RI) levels. Data 
collection in this study used a qualitative approach, then the collected data were analyzed qualitatively, including: data reduction, data presentation, drawing conclusion/verification (Miles \& Huberman, 2005). Furthermore, to systematize the writing of this paper, then it is organized as follows: first, a brief presentation of the theory of power and political dynasties as data interpretation tools; second, a brief profile of the women's legislative and election results; third, vote mobilization strategy and electability analysis.

\section{THEORETICAL FRAMEWORK}

\section{Power and Political Dynasty}

In the discussion of political science, power is one of the important studies. The relationship between politics and power makes every discussion about politics always involves its power in it. Budiarjo (2008) defines power as the ability of a person or a group to influence the behavior of other people or groups in line with the wishes of the perpetrators. Thus, power implies the ability to influence others in terms of actions, thoughts and political attitudes.

The source of power can be physical violence, position, wealth or trust. The position is obtained by means of physical power, inheritance, appointment and so forth. Wealth is obtained by controlling several economic resources or inheritance.
While, trust is obtained by getting the support of the community or a leader who is considered to have authority. Charles F. Andrain (1992) distinguishes power resources into five, namely physical, economic, expertise, normative and personal resources. These power resources can influence other people or groups to do something (see table 1).

In the election context, it is uncommon for the power resources expressed by Andrain to be often practiced stimulatively and partially by the politicians to perpetuate and expand their power. In the ideal understanding, voting is an autonomous activity, in the sense that it is not forced / coerced by other parties. However, the reality on the field, especially in developing countries shows that the voters' behavior is not only determined by the voters themselves but in many cases, it is determined by the pressure of certain groups/leaders (Surbakti, 1992). This dynamic can be used to read the Indonesian context with a variety of elections.

In some areas in the electoral arena, the practice of using threats is still often found to influence the voters, as has been found in North Kolaka and Southeast Sulawesi Zuada and Suaib (2015). Meanwhile, economic power is very much in the voting process of the reform era in Indonesia. Money (wealth) is often used 
Table 1. Types of power resources

\begin{tabular}{|c|c|c|}
\hline $\begin{array}{c}\text { Type of } \\
\text { Resource }\end{array}$ & Example of Resource & Motivation to obey \\
\hline $\begin{array}{c}\text { Physical } \\
\text { resource }\end{array}$ & $\begin{array}{c}\text { Weapons: rifles, bombs, missiles, } \\
\text { other weapons. }\end{array}$ & $\begin{array}{c}\text { B tries to avoid physical injuries } \\
\text { that can be caused by A }\end{array}$ \\
\hline $\begin{array}{c}\text { Economy } \\
\text { resource }\end{array}$ & $\begin{array}{c}\text { Wealth, income, control over goods } \\
\text { and services. }\end{array}$ & B tries to get wealth from A \\
\hline Normative & $\begin{array}{c}\text { Morality, truth, tradition, religion, } \\
\text { legitimacy, authority. }\end{array}$ & $\begin{array}{c}\text { B recognizes that A has the moral } \\
\text { right to regulate B's behavior }\end{array}$ \\
\hline Personal & $\begin{array}{c}\text { Personal charisma, attractiveness, } \\
\text { friendship, affection, popularity. }\end{array}$ & $\begin{array}{c}\text { B identifies himself - feels } \\
\text { interested - with A }\end{array}$ \\
\hline Specialist & $\begin{array}{c}\text { Information, knowledge, intelligence, } \\
\text { technical expertise. }\end{array}$ & $\begin{array}{c}\text { B feels that A has more knowledge } \\
\text { and expertise. }\end{array}$ \\
\hline
\end{tabular}

Source: Andrain (1992).

by the politicians as a means of influencing voters and voter organizers, as written by several scholars, such as Aspinall and Sukmajati (2015), Muhtadi (2017) Zuada and Suaib (2015).

Moreover, normative power (the use of authority/position) in influencing the voters is often used by the politicians who are popular with the term bureaucracy politicization. The study conducted by Agustino (2014) in the Takalar District Election and Jambi Province found that bureaucracy was used as a distribution tool for the interests of the authorities. Various forms of bureaucratic politicization include the use of state facilities, mobilization of civil servants, the compensation of position, politicization of new employees' recruitment, commercialization of positions to dismiss positions (Martini, 2010). The influence of personal power is also an attraction for politicians. Changes in the voters' behavior from flow-based to figure-based (Darmawan, 2015) are the driving factors for celebrities. Popular artist figures are very instrumental in attracting voters' support. Likewise, one's expertise becomes an attraction for the voters.

The choice of candidates or the politicians in political content is also influenced by the factors from political dynasty. The term political dynasty refers to the ability of a family to inherit and accumulate power and wealth from one generation to the next which takes place in all models of the political system (McCoy, 2002; Purdey, 2016). In addition, Thompson (2012) confirms that the political dynasty as another type of direct or indirect transition of political power that involves family members. Furthermore, Querubin (2012) also defines a political dynasty as one or a small number of 
families that dominate the distribution of power in certain areas. Another definition stated by Kenawas (2015), political dynasty refers to elected public officials -governors/mayors/regents/legislators, who have a family relationship with the incumbent at the same time, lower or higher (district or province) based on the husband and wife's relationship, vertical descent or extended family.

Another case confirmed Djati (2013) who called the political dynasty as a practice of familism. Djati said that there were at least three variants of familism in political dynasty. The first is familism, which is a political dynasty that is based purely on direct blood relations in the family (consanguinity) and marital relation (marriage) with other clans. Second, quasi-familism, that is, the political dynasty, is no longer in the realm of the core family, but has also branched out with other families that are not from one bloodline, but have artificially based kinship system. In the quasi-familism model, all family members try to identify themselves through certain symbols in order to get legitimacy from other families. The identification process can be through the use of family names, marriage routes, and other family rites. Third is egoismfamilism. The context of egoism can be understood in two ways, from the side of the authority/ruler and the community.
First, from the side of the ruler, where the ruler replaced still has an influence on his successor both directly and indirectly, giving rise to the interpretation that there is a shadow government that has been carried out by the previous ruler over his successor. From the side of the community, egoism itself is shown by the tendency to keep certain families in control of power.

\section{RESULT AND DISCUSSION}

\section{Brief Profile of Women's Legislative} Election Results in Southeast Sulawesi

Southeast Sulawesi is a province in the Sulawesi peninsula which provides hope for women, especially in the political arena. Imagine, when there are still many people who are studying and questioning the influence of affirmative action on increasing women's electability, women in Southeast Sulawesi had succeeded in penetrating the rigors of competition in the political world, after they were successfully elected as legislative members at the provincial (Regional People's Representative Councils) and national (House of People's Representatives) levels.

Since the enactment of women's quota in the 2004 election, the number of women's representation at the provincial (Regional People's Representative Councils) and national (House of People's 
Table. 2. Profile of elected women candidates on the Provincial House of Representatives (DPRD Province) and the House of People's Representatives (DPR-

$\mathrm{RI})$ in the Southeast Sulawesi electoral district in the results of the 2014 election

\begin{tabular}{|c|c|c|c|c|c|c|}
\hline No & Name & $\begin{array}{l}\text { Organization when } \\
\text { elected }\end{array}$ & Party & $\begin{array}{c}\text { Legislative } \\
\text { Level }\end{array}$ & Constituency & Power Relation \\
\hline 1 & $\begin{array}{l}\text { Asnawati } \\
\text { Hasan }\end{array}$ & $\begin{array}{c}\text { Chairman of } \\
\text { harma Wanita Southeas } \\
\text { Sulawesi Province }\end{array}$ & $\begin{array}{l}\text { PAN } \\
\text { Party }\end{array}$ & $\begin{array}{l}\text { House of People's } \\
\text { Representatives }\end{array}$ & Southeast Sulawesi & $\begin{array}{l}\text { The Wife of Southeast } \\
\text { Sulawesi Governor, Nur } \\
\text { Alam }\end{array}$ \\
\hline 2 & $\begin{array}{l}\text { Murniati M. } \\
\text { Ridwan }\end{array}$ & $\begin{array}{c}\text { Chairman of } \\
\text { Dharma Wanita North } \\
\text { Buton } \\
\text { Regent }\end{array}$ & $\begin{array}{l}\text { PAN } \\
\text { Party }\end{array}$ & $\begin{array}{c}\text { Provincial } \\
\text { House of } \\
\text { Representatives }\end{array}$ & \begin{tabular}{|c|} 
Constituency III \\
Southeast Sulawesi \\
Muna and North \\
Buton)
\end{tabular} & $\begin{array}{l}\text { The wife of the North Buton } \\
\text { Regent, Ridwan Zakaria }\end{array}$ \\
\hline 3 & $\begin{array}{l}\text { Waode } \\
\text { Farida }\end{array}$ & $\begin{array}{c}\text { Chairman of } \\
\text { Dharma Wanita } \\
\text { Muna Regent }\end{array}$ & $\begin{array}{l}\text { PAN } \\
\text { Party }\end{array}$ & $\begin{array}{c}\text { Provincial } \\
\text { House of } \\
\text { Representatives }\end{array}$ & $\begin{array}{c}\text { Constituency III } \\
\text { Southeast Sulawesi } \\
\text { (Muna and North } \\
\text { Buton) }\end{array}$ & $\begin{array}{l}\text { The wife of Muna Regent, } \\
\text { Laode Baharuddin }\end{array}$ \\
\hline 4 & $\begin{array}{l}\text { Isyatin } \\
\text { Syam }\end{array}$ & $\begin{array}{c}\text { Chairman of } \\
\text { Dharma Wanita North } \\
\text { Konawe Regent }\end{array}$ & $\begin{array}{l}\text { Demokrat } \\
\text { Party }\end{array}$ & $\begin{array}{l}\text { Provincial } \\
\text { House of } \\
\text { Representatives }\end{array}$ & \begin{tabular}{|c|} 
Constituency VI \\
Southeast Sulawesi \\
(Konawe and \\
North Konawe)
\end{tabular} & $\begin{array}{l}\text { The wife North Konawe } \\
\text { Regent, Aswad Sulaiman }\end{array}$ \\
\hline 5 & $\begin{array}{l}\text { Yati } \\
\text { Lukman }\end{array}$ & $\begin{array}{l}\text { Former Chairman } \\
\text { of Dharma Wanita } \\
\text { Konawe Regent }\end{array}$ & $\begin{array}{l}\text { Nasdem } \\
\text { Party }\end{array}$ & $\begin{array}{l}\text { Provincial } \\
\text { House of } \\
\text { Representatives }\end{array}$ & $\begin{array}{l}\text { Constituency VI } \\
\text { (Konawe and } \\
\text { North Konawe) }\end{array}$ & $\begin{array}{l}\text { The wife of Regional } \\
\text { Secretary of Southeast } \\
\text { Sulawesi Province and } \\
\text { Former Regent of Konawe in } \\
\text { the two Period, Lukman } \\
\text { Abunawas and in-Law } \\
\text { Deputy Regent of Konawe, } \\
\text { Parinringi. }\end{array}$ \\
\hline 6 & $\begin{array}{l}\text { Waode Sitti } \\
\text { Nurlaila }\end{array}$ & $\begin{array}{l}\text { Former Chairman } \\
\text { of Dharma Wanita } \\
\text { Muna Regent }\end{array}$ & $\begin{array}{l}\text { Golkar } \\
\text { Party }\end{array}$ & $\begin{array}{l}\text { Provincial } \\
\text { House of } \\
\text { Representatives }\end{array}$ & \begin{tabular}{|c|} 
Constituency III \\
poutheast Sulawesi \\
(Muna and North \\
Buton)
\end{tabular} & $\begin{array}{l}\text { The ex-wife of a member of } \\
\text { the Indonesian Parliament } \\
\text { and former Muna Regent, } \\
\text { Ridwan Bae and biological } \\
\text { brother of Muna Regent } \\
\text { Laode Baharuddin }\end{array}$ \\
\hline 7 & $\begin{array}{l}\text { Waode } \\
\text { Salmatia }\end{array}$ & $\begin{array}{c}\text { ormer Chairman Dharm } \\
\text { Wanita } \\
\text { Buton Regent }\end{array}$ & $\begin{array}{l}\text { Demokrat } \\
\text { Party }\end{array}$ & $\begin{array}{c}\text { Provincial } \\
\text { House of } \\
\text { Representatives }\end{array}$ & $\begin{array}{c}\text { Constituency IV } \\
\text { (Buton, Bau-Bau, } \\
\text { Wakatobi) }\end{array}$ & $\begin{array}{l}\text { The wife of the former Buton } \\
\text { Regent, Laode Muh. Syafie } \\
\text { Kahar. }\end{array}$ \\
\hline 8 & $\begin{array}{l}\text { Suryani } \\
\text { Imran }\end{array}$ & $\begin{array}{l}\text { Chairman of } \\
\text { Dharma Wanita } \\
\text { South Konawe } \\
\text { Regent }\end{array}$ & $\begin{array}{l}\text { Golkar } \\
\text { Party }\end{array}$ & $\begin{array}{l}\text { Provincial } \\
\text { House of } \\
\text { Representatives }\end{array}$ & $\begin{array}{l}\text { Constituency II } \\
\text { (South Konawe } \\
\text { and Bombana) }\end{array}$ & $\begin{array}{l}\text { The wife of South Konawe } \\
\text { Regent, Imran }\end{array}$ \\
\hline 9 & $\begin{array}{c}\text { Nirna } \\
\text { Lachmudin }\end{array}$ & - & $\begin{array}{l}\text { Hanura } \\
\text { Party }\end{array}$ & $\begin{array}{c}\text { Provincial } \\
\text { House of } \\
\text { Representatives }\end{array}$ & $\begin{array}{l}\text { Constituency I } \\
\text { (Kendari City) }\end{array}$ & $\begin{array}{l}\text { The wife of } \\
\text { businessman/contracto, } \\
\text { Ishak Ismail }\end{array}$ \\
\hline
\end{tabular}

Representatives) levels in the Southeast

Sulawesi electoral district has continued to increase, although the number has never reached $30 \%$ (Hillman, 2018). In the 2004 General Election, at the Provincial House of Representatives level, it was recorded that the number of women's representation ranged from $8.8 \%$ (4 out of 45 members). Furthermore, in the 2009 Election, women's representation increased to $13.3 \%$ (6 out of 45 members), and in the 2014 Election, the number of women's representation again increased to control $17.8 \%$ (8 out of 45 members)

Regional

People's Representative Councils seats. The increase in legislative seats by women continued in the 2019 election, where 9 $(20 \%)$ women were successfully elected as the members of the Southeast Sulawesi Regional People's Representative Councils. The increase in women's representation at the provincial level also occurred at the national level of Indonesian 
Figure 1. The comparison of candidates' election based on network power in 2014 and 2019 elections

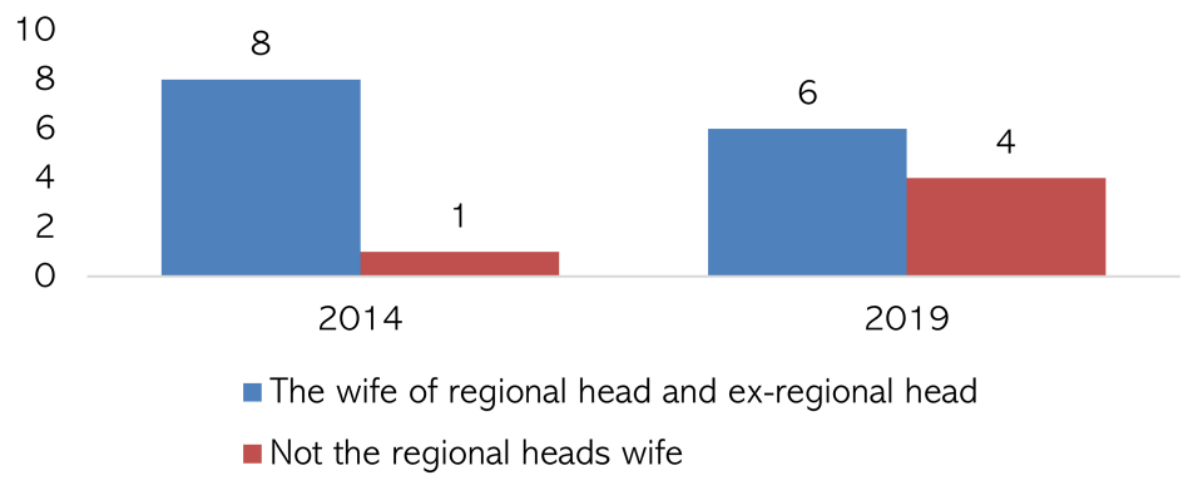

Parliament while in the 2004 Election because they do not have sufficient none of the women representatives passed political experience or in other terms, they through the Southeast Sulawesi electoral are new politicians. Previously these district, yet on 2009, 2014 and 2019 women have never been involved in elections women representatives politics, other than accompanying their succeeded in breaking through intense husbands. Thus, the success of these competition in the race for national women is inseparable from the political legislative seats. Based on the calculation influence held by their husbands. As of the General Election Commission, regional heads and former regional heads, Southeast Sulawesi women succeeded in their husbands still hold control and delivering 1 representative. One of the maintain the social networks and interesting things about the election of the community power in the government, such women is that they come from political as bureaucracy, community leaders and families of the ruling, namely the wife of financial resources. This reinforces the the Regional Head and Former Regional Head, as shown in the table 2.

Based on the table above, we can see that the elected women are dominated by the family background of the regional head view that the political factors (networks power) largely determine the choice of women candidates in the 2014 legislative election.

The influence of this networks' power and former regional head (Fattore et al., still seems to dominate the choice of 2010). The election of the wives of women in the 2019 election, although it regional heads and former regional heads tends to decrease in the number (Prihatini, has been predicted by many parties, 2019). Based on the election results for although their capacity is very doubtful, provincial (Regional People's 
Table 3. Elected women candidates in 2019 election on the Provincial House of Representatives (DPRD Province) and House of People's Representatives of the

Southeast Sulawesi electoral district

\begin{tabular}{|c|c|c|c|}
\hline No & Name & Party & Information \\
\hline 1 & Asnawati Hasan* & $\begin{array}{l}\text { Nasdem } \\
\text { Party }\end{array}$ & Incumbent (Moved from PAN) \\
\hline 2 & Murniati M. Ridwan & PAN Party & Incumbent \\
\hline 3 & Yati Lukman & $\begin{array}{l}\text { Nasdem } \\
\text { Party }\end{array}$ & $\begin{array}{c}\text { Incumbent/the wife of the active Deputy } \\
\text { Governor, Lukman Abunawas }\end{array}$ \\
\hline 4 & Waode Sitti Nurlaila & Golkar Party & Incumbent \\
\hline 5 & $\begin{array}{l}\text { Titin Nurbaya } \\
\text { Saranani }\end{array}$ & PAN Party & $\begin{array}{c}\text { Newcomer/the wife of the active regent of } \\
\text { Konawe, Kerry Saiful Konggoasa. }\end{array}$ \\
\hline 6 & Nurlin Surunuddin & Golkar Party & $\begin{array}{l}\text { Newcomer/the former of Kendari DPRD } \\
\text { member/the wife of the active regent of } \\
\text { South Konawe, Surunuddin Dangga }\end{array}$ \\
\hline 7 & Sulaeha Sanusi & PDIP Party & Incumbent/cadre of PDI-P \\
\hline 8 & Sitti Nurhayati & $\begin{array}{l}\text { Nasdem } \\
\text { Party }\end{array}$ & Newcomer/cadre of Nasdem \\
\hline 9 & $\begin{array}{c}\text { Farhana } \\
\text { Malawangan }\end{array}$ & Golkar Party & $\begin{array}{l}\text { Newcomer/Chair of the Golkar Party } \\
\text { Women's Coalition Southeast Sulawesi }\end{array}$ \\
\hline 10 & Sri Susanti & PBB Party & $\begin{array}{c}\text { Newcomer/Former North Konawe DPRD } \\
\text { member/cadre of PBB }\end{array}$ \\
\hline
\end{tabular}

Representative Councils) and national from the wives of the regional head/former (House of People's Representatives) seats, regional head.

out of the 10 elected female candidates in

Farhanan Malawangan is one of the Southeast Sulawesi, as many as 6 people come from the families of the regional heads/the former regional heads, as shown in the figure 1.

The reduce in the dominance of the wives of regional heads/former regional heads is shown by the brief background of elected women who become the members of Regional People's Representative Councils (DPRD) (see table. 3), where the four elected DPRD members, namely Sulaeha Sanusi, Sitti Nurhayati, Sri Susanti and Farhana Malawangan do not come elected women candidates from the Golkar party. She is an active cadre of the Golkar Party who occupies the structural position as The Chair of Golkar Party Women's Union. Besides being known as a politician, Farhana also is known to have a wide network of friends. Before being elected as a member of the Regional People's Representative Councils, she was the Chairperson of Pomalaa 1 Junior High School Alumni Association. Pomalaa is a sub-district in Kolaka Regency, which is popular with the presence of PT. ANTAM, a national nickel mining company. During 
Figure 2. The election of women by membership status in the 2014 and 2019 elections

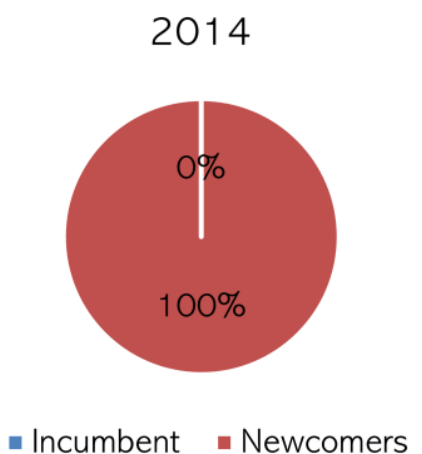

the campaign, Farhana actively used the alumni network to conduct social activities. In her campaign activities, Farhana introduced herself by utilizing social media on Instagram and YouTube. She is also known as a politician who has a beautiful face. Based on the calculation result of The General Elections Commission, she was declared to qualify as a member of the Provincial House of Representatives after defeated her rival, Ismail Iskandar. The election of Farhana Malawangan was said to be inseparable from the financial strength because she used approximately three billion to pay voters. Farhan Malawangan is also often referred to as a loyalist of the Chairman Golkar Regional Representative Council of Southeast Sulawesi, namely Ridwan Bae, who is running for House of People's Representatives. Ridwan Bae, besides being well-known as a popular politician, he is also known to be very generous in financing political costs.

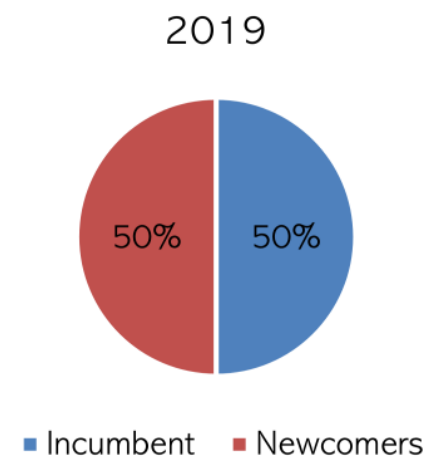

A very distinctive achievement was noted by Sulaeha Sanusi, a woman politician from PDIP who succeeded in winning the election after defeated popular figures from her party, such as former Kendari City Secretary, Alamsyah Lotunani and young politician/former of Indonesian Youth National Committee chairman, Laode Umar Bonte. Sulaeha Sanusi was born in Lambuy. In the previous period, she was the member of the Southeast Sulawesi Provincial House of Representatives (Konawe and North Konawe) who sat after an interim (change between times) towards Litanto who advanced as Konawe Regent. In the 2019 election, Sulaeha Sanusi went forward as a legislative candidate for the Southeast Sulawesi Provincial House of Representatives through the Sultra 1 constituency (Kendari City). Another woman who managed to sit as a member of the Southeast Sulawesi Regional People's Representative Councils was Sitti Nurhayati, a Nasdem politician 
who ran for the Southeast Sulawesi constituency (Kolaka, North Kolaka and East Kolaka). Similar to the two previous politicians, Sitti Nurhayati is a politician who is not from the family of the regional head/former regional head. Another woman politician who passed the Provincial House of Representatives was Sri Susanti. Sri Susanti before entering Provincial House of Representatives was a member of the North Konawe District (Regional People's Representative Councils) from the PBB Party, this party at the District Council level was chaired by the 2015-2020 North Konawe Regent, Ruksamin.

Another portrait was found when observing the election of women in the legislative, namely the lack of political experience owned by those women. The legislative election in 2014 was success in delivering 8 women in the provincial legislative seat and 1 woman in the national legislative seat. In this election the elected women were those who had never entered politics in the past, so that they could be categorized as newcomers. In the 2019 election, the legislative composition would no longer be filled with new faces. Instead, $50 \%$ of them were incumbent politicians who were re-elected. The incumbent was even more than $50 \%$, if it was calculated from their political experience. Nurlin Surunuddin and Sri
Susanti, both were the political newcomers in the provincial legislative. However, they previously had political experience at the legislative level in Kendari City and North Konawe Regent.

\section{Vote Mobilization Strategy and Election Analysis}

The election of women who are not from the family of the regional head/ former regional head indicates that the political factor (network) is not the main instrument of women's choice. Instead, there are various other factors, such as political activity in the party, political experience, financial strength, and ethnic competition. The election process in Southeast Sulawesi is often characterized by ethnic competition (Sjaf, 2014), money politics (Suaib, 2017; Zuada \& Suaib, 2015; Anggraini et al., 2017) and political dynasty (Nurdin et al., 2017). These three things often support the election of a candidate in electoral competition for executive and legislative positions. In the struggle for legislative seats, the practice of money politics and bureaucratic politicization were found in influencing the election of female legislative candidates in the 2014 election in Southeast Sulawesi.

In the 2014 election, the Governor Nur Alam successfully delivered his wife Asnawati Hasan as the member of House of People's Representatives from 
Southeast Sulawesi after surpassing Laode Ida. Tina's victory (greeting Asnawati) was inseparable from the role of her husband who held control of the bureaucracy, election organizers, regents/mayors and games of money politics (kompas, 2014). The same step was taken by the North Konawe Regent, Aswad Sulaiman in 2014, he succeeded in delivering his wife Isyatin Syam to be elected as the member of the Southeast Sulawesi Regional People's Representative Councils. The election of Isyatin Syam was also inseparable from her husband's role in distributing money during the campaign (Tribunnews, 2014). In the bureaucratic ranks, Aswad Sulaiman strengthened his political influence by appointing his two sons as the Head of the Public Works Service and the Head of the Regional General Hospital in North Konawe (Zuada \& Suaib, 2015).

During the 2014 legislative election in North Buton, Ridwan Zakaria encouraged his wife as a provincial legislative candidate through PAN party, the party he dreamed of in North Buton. The victory of Murniati Ridwan Zakaria could not be separated from her husband's support in the bureaucracy, election organizers and money politics (Nurdin, 2017). Based on the recognition of one party's competitor, Murniati Ridwan allegedly played votes theft which was involving election organizers. In political terminology, the event of votes theft involves popular election organizers which are referred to as vote trading. The use of bureaucratic power also used by dr. Baharuddin in the Regency in the effort to pass his wife, Waode Farida in the 2014 election. The same step was taken by the South Konawe Regent, Imran, in order to pass his wife Suryani Imran. Bureaucratic mobilization was allegedly carried out by Lukman Abunawas, Regional Secretary of the Southeast Sulawesi Province who succeeded in delivering his wife as a member of the Southeast Sulawesi Regional House of Representatives.

In the 2019 election, vote mobilization strategy through money politics, the power of bureaucratic mobilization and political reciprocity still colored the choice of legislative candidates, including women. The use of bureaucracy and money politics was used by the wife of the active regional head, Titin Nurbaya Saranani (the wife of the Konawe Regent). Titin Nurbaya Saranani used the village apparatus as a money distribution team. Moreover, besides money, she was also found distributing groceries to the residents (Inilahsultra, 2019). The use of bureaucratic power and money politics was also used by Nurlin Surunuddin (wife of the South Konawe Regent). At the event held at the Regent's residence, the Regency bureaucratic 
apparatus, the Head of Village until the leader of neighborhood association in South Konawe were collected and given money to win Nurlin Surunuddin in the Provincial House of Representatives seat. The mobilization of the bureaucratic apparatus and money politics were smelled and submitted by the Election Supervisory Agency, but it escaped from the reporting and simply disappeared, without any clarity of resolution. The use of money politics also carried out by the wife of former regional head who still had financial power. Asnawati Hasan's team participated in distributing money in order to gain votes by using political party networks at the district level. In addition, Asnawati Hasan received political support from regional head who still respected Nur Alam's services while still serving as governor. Nur Alam was known to still maintain political connections with her former subordinates, as was done by the Think Tank Rajiun Center that fully supported the election process of Tina Nur Alam (Asnawati Hasan).

In addition, the elected candidates in Southeast Sulawesi were also very influenced by their network of friends. This was as found in Farhana Malawangan, the alumni bond network where she went to school and it was used to socialize herself and carry out social activities, such as: holding competitions, visiting teachers and friends of alumni who were sick and grieving, social service to clean graves and other various social activities. The mobilization strategy used by Farhana Malawangan resembled the mobilization of friends and neighbors mentioned by Panagopoulos and Bailey (2020). The study conducted by Panagopoulos and Bailey (2020), in the United States found that the mobilization of 'friends-neighbors' was used by the politicians to gain vote support. This 'friends-neighbors' strategy could indeed explain the choice of Farhana Malawangan, although this did not become the main support. The mobilization of 'friends-neighbors' will be sluggish without being accompanied by the power of financial resources (money). This case had occurred in the general election process in Southeast Sulawesi in recent years. The candidates who are known to be popular, have strong organizational networks, family networks, as well as networks of friends and neighbors, are defeated by the politicians who are minimal in the organization and come from outside the region (different ethnicities) but do distribution of money politics. The malfunctioning of neighboring and ethnic (locality) networks is the evident in the 2017 Kendari City Election, where money mobilization had succeeded in defeating ethnic mobilization (Husain \& Zuada, 2019). Departing from that, it can be said 
that the network of friends will shut down and even die if it is not supported by the power of money. Like a motorbike, friends and neighbors are the engine and wheels, while money is the fuel. Both are inseparable things.

In relation to money politics, there are the growth of new patrons that play an important role in the relationship between the candidates and the voters. Many community leaders, formal figures, or ordinary community members work on behalf of candidates (Panagopoulos \& Bailey, 2020). Their main task is to persuade their neighbors and acquaintances to choose the candidate. Often, efforts are made by giving money. This is done by the candidates, because they can not possibly interact directly with many voters, besides the candidates are carefully distributing money with the aim is to avoid the legal trap. Therefore, they need agents who can work on their behalf, organize campaigns, and convey information about candidate profiles to the voters. So, money politics occurs because of the electoral design that relies on the ability of candidates to design, run and fund all political activities. The influence of the power of money makes capacity and capability not so significant. Money is also able to defeat the social capital that has been formed for a long time in society, such as activists, youth leaders, and former officials. Long and short story is that money can be a determining factor in the choice of politicians in Southeast Sulawesi.

\section{CONCLUSION}

The election of women in Southeast Sulawesi as the members of House of People's Representatives and Provincial House of Representatives in the 2014 and 2019 elections can be divided into two main patterns. First, most of the women who sit as the members of the House of People's Representatives and Provincial House of Representatives have a source of power from their husbands who is an official or former official. These husbands have a strong network by controlling power resources in the form of normative sources, namely as public officials who have the authority to move the bureaucratic network, then economic resources with money politics during the election. Second, women who are not from the families of public officials have been elected because they have power resources in the form of personal resources, where they are cadres of political parties and have close relations with politicians in Southeast Sulawesi. Furthermore, these women were also supported by strong economic resources, because it was found that some of them were involved in money politics. 
This study found that out of the five indicators of power sources according to the theory by Charles F. Andrain, only confirmed three power resources used, namely economic, normative and personal sources. There is no power held by women in the form of physical coercion, nor does it originate from the source of their expertise, so that they can be elected as the members of the House of People's Representatives and Provincial House of Representatives (Jones, 2010). This research confirms some of Andrain's power resource theory (1992). In the context of Southeast Sulawesi, this study found a change in the vote mobilization strategy. Ethnic mobilization (locality) that characterizes the local politics of Southeast Sulawesi has a smaller electoral influence, whereas money politics (economic resource) and bureaucratic politicization (normative) strongly influence the voters. Thus, this study enriches the findings in the vote mobilization strategy, namely the combination of locality/friends-neighbors (ethnicity), money and bureaucracy as the factor of politicians' electability.

\section{REFERENCES}

Afrianty, D. (2015). Indonesian women and local politics: Islam, gender and networks in post-Suharto Indonesia.
Southeast Asian Studies, 4(3), 614. Google Scholar

Agustino, L. (2014). Patronase Politik Era

Reformasi: Analisis Pilkada di Kabupaten Takalar dan Provinsi Jambi. Jurnal Administrasi Publik, 11(2). Google Scholar

Andrain, C. F. (1992). Kehidupan Politik dan Perubahan Sosial. Yogyakarta:

Tiara Wacana. Google Scholar

Anggraini, D., Husain, M. D., Zuada, L. H. (2017). Patronage in the General Election of Local Leader-Pemilukada: An Analysis of Kendari's Mayor Election in 2017. Academic Reseach International, 8(3). Google Scholar

Aspinall, E., \& Sukmajati, M. (2015). Politik Uang di Indonesia: Patronase dan Klientelisme pada Pemilu Legislatif 2014. Yogyakarta: PolGov. Google Scholar

Berg, L. (2015). Women's Pathways into Parliament: The Case of Indonesia. Thesis: Lund University. Google Scholar

Budiarjo, M. (2008). Dasar-Dasar IImu Politik: Edisi Revisi. Jakarta: Gramedia Pustaka. Google Scholar

Darmawan, I. (2015). Keterlibatan selebriti dalam pemilu Indonesia pasca Orde Baru. Sosiohumaniora, 17(3), 230236. Crossref | Google Scholar Darwin, R. L. (2017). The power of female brokers: Local elections in North Aceh. 
Contemporary Southeast Asia, 532-

551. Google Scholar

Djati, W. R. (2014). Revivalisme Kekuatan

Familisme dalam Demokrasi: Dinasti

Politik di Aras Lokal. Masyarakat: Jurnal Sosiologi, 203-231. Crossref I Google Scholar

Fattore, C., Scotto, T. J., \& Sitasari, A (2010). Support for women officeholders in a non-Arab Islamic democracy: The case of Indonesia. Australian Journal of Political Science, 45(2), 261-275. Crossref | Google Scholar

Hillman, B. (2018). The limits of gender quotas: women's parliamentary representation in Indonesia. Journal of Contemporary Asia, 48(2), 322-338. Crossref | Google Scholar

Husain, M. N., \& Zuada, L. H. (2019). Money Politics Beat the Ethnic Politics:

A Case Study Local Election in Kendari. Paper at 3rd Biannual International Conference on Indonesiaan Politics and Goverment (B/COIPG), on 10-11th July, 2019, Faculty of Social and Political Science, Universitas Indonesia. Google Scholar Inilah Sultra Newspaper. (2019). Diduga bagi-bagi Gula Teh, Istri dan Anak Bupati Konawe digarap Bawaslu. Available at: https://inilahsultra.com/ 2019/02/05/diduga-bagi-bagi-gula- teh-istri-dan-anak-bupati-konawe-diga rap-bawaslu/.

Jones, C. (2010). Better women: The cultural politics of gendered expertise in Indonesia. American Anthropologist, 112(2), 270-282. Crossref | Google Scholar

Kenawas, Y. C. (2015). The Rise of Political Dynasties in a Democratic Society. Arryman Fellow Research Paper. Google Scholar

Martini, R. (2010). Politisasi Birokrasi di Indonesia. Politika: Jurnal Ilmu Politik, 1(1), 67-74. Google Scholar

Marwah, S. (2019). Reading Women Participations on Populism Politics. Politik Indonesia: Indonesian Political Science Review, 4(2), 255-273. Crossref | Google Scholar

McCoy, A. W. (2002). Closer than brothers: Manhood at the Philippine military academy. Yale University Press. Google Scholar

Miles, M. B., \& Haberman, A. M. (2005). Qualitative Data Analysis (Terj.). Jakarta: UI Press. Google Scholar Muhtadi, B. (2013). Politik uang dan dinamika elektoral di Indonesia: Sebuah kajian awal interaksi antara "Party-ID" dan Patron-Klien. Jurnal Penelitian Politik, 10(1). Google Scholar 
Nurdin, I., Suaib, E., \& Banne, I. R. (2017). Suaib, E. (2017). Democracy and Filipinazion of Indonesian Politics: Development at the Local Level: Politics of Family Formation in Synergy of Local Boss, Entrepreneur Southeast Sulawesi. Scientific Journal of PPI-UKM, 3(7), 333-340. Google Scholar

Panagopoulos, C., \& Bailey, K. (2020). "Friends and Neighbors" Mobilization: A Field Experimental Replication and Extension. Journal of Experimental Political Science, 7(1), 13-26. Crossref | Google Scholar

Prihatini, E. S. (2019). Women who win in Indonesia: The impact of age, experience, and list position. Women's Studies International Forum, 72, 4046. Pergamon. Google Scholar

Purdey, J. (2016). Political Families in Southeast Asia. Journal South East Asia Research, 24(3), 319-327. Crossref | Google Scholar and Bandit in North Kolaka. In Third International Conference on Social and Political Sciences (ICSPS 2017). Atlantis Press. Crossref

Surbakti, R. (1992). Memahami IImu Politik. Jakarta: PT. Grafindo. Google Scholar

Thompson, M. R. (2012). Asia's hybrid dynasties. Asian Affairs, 43(2), 204220. Crossref | Google Scholar

Tribunnews. (2014). Bupati Konawe Utara Terancam Dipenjara karena Bagi Duit saat Kampanye Partai Demokrat. Available at: https://www.tribunnews .com/regional/2014/04/16/bupati-ko nawe-utara-terancam-dipenjara-karena -bagi-duit-saat-kampanye-partai-demo krat.

Querubin, P. (2012). Political reform and elite persistence: Term limits and political dynasties in the Philippines. In APSA 2012 Annual Meeting Paper. Google Scholar

Shair-Rosenfield, S. (2012). The Zuada, L. H., \& Suaib, E. (2015). Banyak Uang Bukan Jaminan Terpilih (Studi tentang Praktek Money Politics dari Pemilukada Konawe Selatan Tahun 2015). Jurnal Bawaslu, 2, 67-81. alternative incumbency effect: Electing women legislators in Indonesia. Electoral Studies, 31(3), 576-587. Crossref | Google Scholar

Sjaf, S. (2014). Politik Etnik. Yayasan Obor Indonesia; Jakarta. Google Scholar 